\title{
Administering Justice and Serving the People
}

\author{
The Tension between the Objective of Judicial Efficiency and Informal Justice in Canadian
}

Access to Justice Initiatives

Catherine Piché*

\begin{abstract}
Canada has a complex system of courts that seek to serve Canadians in view of the traditional objectives of civil justice - principally accessibility, efficiency, fairness, efficacy, proportionality and equality. The Canadian court system is generally considered by its users to work well and to have legitimacy. Yet, researchers have found that 'there is a tendency for people involved in a civil case to become disillusioned about the ability of the system to effect a fair and timely resolution to a civil justice problem'. This article will discuss the ways in which reforms of procedural law and civil justice have originated and continue to be made throughout Cana$\mathrm{da}$, both nationally and provincially, as well as the trends and influences in making these reforms. With hundreds of contemporary procedural reforms having been discussed, proposed and/or completed since the first days of Canadian colonisation on a national basis and in the Canadian provinces and territory, providing a detailed analysis will prove challenging. This article will nonetheless provide a review of civil justice and procedural reform issues in Canada, focusing principally, at the provincial level, on the systems of Ontario and Quebec. Importantly, I will seek to reconcile the increasing willingness to have an economically efficient civil justice and the increased power of judges in managing cases, with our court system's invasion of ADR and its prioritisation of informal modes of adjudication.
\end{abstract}

Keywords: access to justice, procedural law, courts, civil justice reform, comparative law

\section{Introduction}

Canada has a complex system of courts that seek to serve Canadians in view of the traditional objectives of civil justice - principally accessibility, efficiency, fairness, efficacy, proportionality and equality. The Canadian court system is generally considered by its users to work well and to have legitimacy. ${ }^{1}$ Yet, researchers have found that 'there is a tendency for people involved in a civil case to become disillusioned about the ability of the system to effect a fair and timely resolution to a civil justice problem'. ${ }^{2}$ Even with our organised, public and transparent justice system, most disputes follow the international civil justice trends and are resolved out of court and very few issues proceed formally into the public justice system. ${ }^{3}$ Important barriers to access to justice exist. The system is perceived as slow and expensive, ${ }^{4}$

1. For a study concluding to the public's 'reasonable level of confidence in the civil justice system', see S. Wain, 'Public Perceptions of the Civil Justice System', in Rethinking Civil Justice: Research Studies for the Civil Justice Review (Vol. 1, Toronto, Ontario Law Reform Commission, 1996) (concluding that the 'sense of a 'justice system crisis' which is common among the system's insiders does not appear to be shared by the general public. Public surveys indicate that civil justice reform is not a 'top of the mind' issue for most people.'). Also see more detailed and recent data on the issue of legitimacy and confidence, available at: $<$ www.cfcj-fcjc.org/sites/default/files/docs/2006/shone-final-en.pdf, at $115 \mathrm{ff}>$.

2. M. Stratton and D. Lowe (Canadian Forum on Civil Justice), 'Public Confidence and the Civil Justice System: What Do We Know About the Issues?', prepared for Justice Policy Advisory Subcommittee on Public Confidence Alberta Justice (2006) at 7, available at: <www.cfcj-fcjc.org/ sites/default/files/docs/2006/cjsp-confidence-en.pdf>. Also see J. Silver and T.C.W. Farrow, 'Canadian Civil Justice: Relief in Small and Simple Matters in an Age of Efficiency', 4 Erasmus Law Review 232 (2015) at 232-44.

3. It is anecdotally considered that approximately $5 \%$ of all disputes are resolved in the court system.

4. T.C.W. Farrow, 'What is Access to Justice?', 51 Osgoode Hall Law Journal 3 (2014). Also see <www.thestar.com/opinion/commentary/ 2015/02/25/make-the-justice-system-accessible.html> (article written and published by L. Sossin, Dean of Osgoode Hall Law School at York University, and D. Allgood, General Counsel of RBC Royal Bank, are Ambassadors for Flip Your Wig for Justice.). National ranges of legal fees are recently reported to be $\$ 13,561-\$ 37,229$ for a civil action up to trial (two days), $\$ 23,083-\$ 79,750$ for a civil action up to trial (five days), $\$ 38,296-\$ 124,574$ for a civil action up to trial (seven days) and $\$ 12,333-\$ 36,750$ for a civil action appeal. The length and cost of legal matters have continued to increase. In Ontario, legal aid funding is generally only available for individuals with a gross annual salary of less than $\$ 18,000$, or for a family of four with a total gross annual salary of $\$ 37,000$. See <www.flipyourwigforjustice.ca/access/>. Also see Supreme Court of Canada Chief Justice B. McLachlin, Speech to Canadian Bar Association Council on 11 August 2012, available at: <www. canadianlawyermag.com/4273/Chief-Justice-McLachlin-speech-to-CBA -Council-2012.html>. 
and importantly, close to half of all Canadian users of the judicial system are not represented by an attorney. ${ }^{5}$ On philosophical and sociological levels, public court processes are of fundamental importance in Canada as they relate to 'how citizens govern themselves and regulate their rights and relationships in modern democracies'. ${ }^{6}$ These processes are increasingly required to be efficient, ${ }^{7}$ and efficiency is said to require operations that are 'just, efficient and proportionate to the needs and resources of the citizens'. ${ }^{8}$ As for accessibility of the system, advanced justice systems such as Canada's must provide access to justice to the people they are meant to serve. ${ }^{9}$ According to the Chief Justice of Canada, quoting the former Chief Justice of Ontario, 'access to justice is the most important issue facing the legal system'. ${ }^{10}$ How is this access to be given?

This article will provide an overview of the ways in which reforms of procedural law and civil justice have originated and continue to be made throughout Canada, both nationally and provincially, as well as the trends and influences in making these reforms. With hundreds of contemporary procedural reforms having been discussed, proposed and/or completed since the first days of Canadian colonisation on a national basis and in the Canadian provinces and territory, ${ }^{11}$ providing a detailed analysis will prove challenging. ${ }^{12}$ This article will nonetheless provide a good overview of civil justice and pro-

5. See notably Dr. J. Macfarlane, 'National Self-Represented Litigants Project: Identifying and Meeting the Needs of Self-Represented Litigants', Final Report (Kingsville, 2013) at 14; Remarks of the Right Honourable B. McLachlin, 'Presented at the Empire Club of Canada Toronto' (8 March 2007), available at: <www.scc-csc.gc.ca/court-cour/judges -juges/spe-dis/bm-2007-03-08-eng.aspx\#fnb3>, citing A.-M. Langan, 'Threatening the Balance of the Scales of Justice: Unrepresented Litigants in the Family Courts of Ontario', 30 Queen's L. J. 825 (2005) (citing data according to which in 2003, $43.2 \%$ of applicants in the Family Court Division were unrepresented).

6. Action Committee on Access to Justice In Civil and Family Matters, Report of the Court Processes Simplification Working Group (May 2012), p. 1, available at: <www.cfcj-fcjc.org/sites/default/files/docs/ 2013/Report\%20of\%20the \%20Court\%20Processes\%20Simplification $\% 20$ Working $\% 20$ Group.pdf>.

7. A.S. Zuckerman, 'Reforming Civil Justice Systems: Trends in Industria Countries', The World Bank Premnotes (October 2000, No. 46); A. Zuckerman, P. Gottwald \& S. Chiarloni, eds., Civiljustice in Crisis: Comparative Perspectives of Civil Procedure (Oxford, Oxford University Press, 1999).

8. Ibid. Also see Preliminary Provision of Quebec's Code of Civil Procedure.

9. Ibid., at iii.

10. Ibid., citing Rt. Hon. B. McLachlin, P.C., 'The Challenges We Face' (remarks presented at Empire Club of Canada, Toronto, 8 March 2007), available at: <http://scc-csc.ca/court-cour/judges-juges/spe-dis/bm -2007-03-08-eng.aspx>. Also see Farrow, above n. 4, at 3.

11. See, e.g., Canadian Judicial Council, Sub-committee on Access to Justice (Trial Courts) of the Administration of Justice Committee, 'Access to Justice: Report on Selected Reform Initiatives in Canada', June 2008, available at: <www.cjc-ccm.gc.ca/cmslib/general/2008_ SelectedReformInitiatives_Report_final_EN.pdf $>$. The Report provides information about the many reforms that have been undertaken throughout the country, and confirms that the justice system is undergoing constant review and renewal.

12. For a more complete - while not exhaustive and still a work-in-progress - inventory of reforms, see the public database of the Canadian Forum on Civil Justice, available at: <http://cfcj-fcjc.org/inventory> (Inventory of Reforms). cedural reform issues in Canada, focusing principally, at the provincial level, on the systems of Ontario and Quebec. Importantly, my overview of procedural reforms will seek to reconcile the increasing willingness to have an economically efficient civil justice and the increased power of judges in managing cases, with our court system's invasion of ADR and its prioritisation of informal modes of adjudication.

\section{Overview of the Canadian Civil Justice System and Access to Justice Challenges}

\subsection{The Canadian Legal System}

The Canadian judicial system is a federal one, where the Parliament of Canada and the provincial and territorial legislatures have the jurisdiction to make laws. Parliament can pass laws for all of Canada, but only about matters covered by the Constitution. The judicial system may be imaged in the form of a pyramid, ${ }^{13}$ with at its base the provincial and territorial courts whose judges are appointed by the provincial and territorial governments. Judges at all the other levels are appointed by the federal government. Briefly, the federal, provincial and territorial governments pass laws and share the administration of justice. There are four court levels: (1) provincial courts, which hear the majority of cases that come through the system; (2) provincial superior courts, which hear more serious criminal cases and appeals from the provincial courts; (3) on the same level, the Federal Court of Canada, which hears issues distinct from the other courts, that is, federal law matters; and finally, (4) at the next level, the provincial courts of appeal and the Federal Court of Appeal.

The highest court in Canada is the Supreme Court of Canada. ${ }^{14}$ The Supreme Court sits at the top of the pyramid and is Canada's final court of appeal, deciding legal issues of public importance, and thereby contributing to the development of all branches of law applicable within Canada. The federal courts are the Federal Court of Appeal, the Federal Court, the Tax Court of Canada and the Court Martial Appeal Court. Unlike the provincial superior courts, which exercise inherent jurisdiction, the jurisdiction of these courts is defined by statute and encompasses matters falling within the competence of the federal government.

The superior courts of each province and territory include both a court of general trial jurisdiction and a provincial court of appeal. Importantly, in these courts, jurisdiction is not limited to matters over which the provincial governments have legislative jurisdiction. They have jurisdiction over disputes arising in many of the areas over which the federal government is granted leg-

13. See Supreme Court of Canada Website, which uses this imagery, available at: <www.scc-csc.ca/home-accueil/index-eng.aspx>.

14. See ibid. 
islative jurisdiction in the Constitution Act of 1867. To address certain areas of the law more effectively, specialised courts were created, such as the Tax Court of Canada and the military tribunals. Accordingly, the Canadian legal system provides institutionalised processes with overlapping provincial, territorial and federal jurisdictions. There are family, youth, criminal and administrative divisions and substantive and procedural laws are made applicable to all situations.

In Canada, our human rights and fundamental freedoms are thoroughly and exceptionally protected under the Constitution, as well as federal, provincial and territorial laws. The 1960 Canadian Bill of Rights, ${ }^{15}$ was the first federal human rights law in Canada. It guaranteed several basic rights and freedoms, including the 'right of the individual to life, liberty, security of the person and enjoyment of property' and the right not to be deprived of any of those rights except in accordance with 'due process', meaning basic procedural fairness. In 1977, the Canadian Human Rights Act ${ }^{16}$ was then passed, also protecting human rights but in the federal public and private sectors. The provinces and territories have further enacted legislation protecting human rights and prohibiting discrimination in employment and housing and in providing goods, services and facilities to the public. In the 1982 Canadian Charter of Rights and Freedoms, ${ }^{17}$ human rights in Canada were officially protected in a written Constitution.

Judicial independence is one fundamental guarantee and principle of the Canadian judicial system. ${ }^{18}$ In fact, it is one of the most important underlying principles of any democratic society. Under the Canadian Constitution, the judiciary is separate from and independent of the other two branches of government, the executive and the legislative. Judicial independence is provided through security of tenure and financial security and administrative independence. This principle guarantees that judges will decide free of influence and solely based upon facts and law. This guarantee is fostered by several Canadian Federal Government institutions such as the National Judicial Institute, the Canadian Judicial Council and the Commissioner for Federal Judicial Affairs.

More importantly, the Supreme Court of Canada, in a series of decisions, has insisted on the cornerstone principle of judicial independence, and on the fact that it has both an individual and an institutional component. ${ }^{19}$ The Supreme Court, as such, has specified that a number of conditions are essential to judicial independence, including financial security and security of tenure, and that the relative importance of these conditions may evolve with time and circumstances. ${ }^{20}$ The Canadian

15. Canadian Bill of Rights, S.C. 1960, c. 44, Assented to on 10 August 1960.

16. Canadian Human Rights Act, R.S.C., 1985, c. H-6.

17. Constitution Act (1982), available at: <http://laws-lois.justice.gc.ca/ eng/const/page-15.html>.

18. P. Noreau and E. Bernheim, Applied Judicial Ethics (3rd edn., Montreal, Wilson \& Lafleur 2014).

19. R. v. Valente, [1985] 2 S.C.R. 673 at 687; R. v. Beauregard, [1986] 2 S.C.R. 56 at 70; MacKeighan v. Hickman, [1989] 2 S.C.R. 796.

20. Ibid
Bar Association expressed, in its 1996 Report of the Task Force on Systems of Civil Fustice, the need, given dwindling resources and ever-increasing needs in the Canadian justice system, that 'any reforms, including recommendations directed to the system's management and resources, (take) into account the fundamental need to preserve and enhance judicial independence in both its individual and institutional elements'. ${ }^{21}$

\subsection{The Barriers to Access to Justice in Canada}

To better understand directions for reform and reform processes, it is important to look behind the system and address the traditional and contemporary barriers to access to justice. Access to justice is commonly understood today as extending beyond access to lawyers and to courts. It is conceived as requiring a range of ways to prevent and resolve everyday legal problems, and must involve fair processes and just outcomes. In fact, as aptly described by the Canadian Forum on Civil Justice, 'access to justice refers broadly to the access that citizens have to dispute resolution tools of justice including but not limited to courts [...] it is a broad term that refers more generally to the efficaciousness of a justice system in meeting the dispute resolution needs of its citizens'. ${ }^{22}$ In 1996, the Canadian Bar Association issued a report entitled Report of the Task Force on Systems of Civil Fustice ${ }^{23}$ in which it highlighted the general perception of fairness and equal treatment by users of the Canadian justice system, as well as the levels of procedural and substantive fairness generally achieved in the system. ${ }^{24}$ It further indicated that the civil justice system provides a relatively cost-efficient and speedy judicial resolution, and that the fact that between $95 \%$ and $97 \%$ of cases commenced in the civil justice system are settled or abandoned is probably due to the competence and reasonableness of lawyers and their clients in resolving disputes voluntarily outside of the courts. ${ }^{25}$

While the Canadian system appears modern, equitable and strong, several important barriers to access to justice have nonetheless existed for more than 20 years $^{26}$ and continue to exist. These have been the subject of numerous reforms and task force reports in recent years. Importantly, to evaluate and compare Canada's system with the rest of the world, the reputable World Justice Index must be consulted. ${ }^{27}$ In 2016, the Index surprisingly ranked Canada at the twelfth place on 102 countries (and down from the eighth place in 2014), princi-

21. Report of the Task Force on Systems of Civil Justice, Ottawa, Canadian Bar Association National Task force on Systems of Civil Justice (August, 1996) at 4 (Thereinafter 'CBA Task Force Report').

22. Canadian Forum of Civil Justice Website, available at: <www.cfcj-fcjc. org/projects>. Also see, generally Farrow, above n. 4, at 3.

23. CBA Task Force Report, above n. 21.

24. Ibid., p. 11

25. Ibid.

26. A.J. Roman, 'Barriers to Access: Including the Excluded', in A.C. Hutchison (ed.), Access to Civil Justice (Toronto, Carswell, 1990).

27. See Rule of Law Index (2016), available at: <http://data. worldjusticeproject.org/\#/index/CAN>. 
pally due to the lack of affordability and accessibility of legal services. ${ }^{28}$

In fact, the first and foremost problem with Canadian access to justice is access to legal representation, since approximately $50 \%$ of all Canadians are not represented by counsel in the courts. Indeed, with more than 920,000 active cases working their way through Canada's civil court system per year, one in five Canadians is a user of the system, but only $45 \%$ of those users hire lawyers to represent them and only $28 \%$ consult with a lawyer. ${ }^{29}$

In addition, there is a lack of accessibility due to "the (tremendous) cost and time involved in navigating the Canadian system'. ${ }^{30}$ As has stated the Ontario Ministry of the Attorney General, '[m] ost litigants simply want to have their disputes resolved quickly and cheaply, and to move on with their lives. Delays in proceedings are legion, however, and their associated costs enormous. Cost and delay are the twin enemies of the civil justice system'. ${ }^{31}$ In 1996, the CBA Task Force Report reasoned that the following three issues in the Canadian civil justice system needed to be prioritised: the speed with which disputes are resolved in the civil courts; the affordability of dispute resolution in the civil courts; and public understanding of the work of the courts and the system as a whole. ${ }^{32}$

The problem of costs and delays, however, is considered to be universal and long-standing. There have historically always been delays associated with court cases and using the court system has traditionally been considered to be expensive. Problems of delay include delays in commencing and handling and organising a case, which are directly correlative with litigation costs. ${ }^{33}$ Generally, the use of the justice system involves high costs for the users, particularly for claims that do not involve large sums of money, and often restrict these users' outright access to the system. ${ }^{34}$ Great numbers of Canadians are actually unable to gain access to the civil justice system because of the cost and because the country's legal aid or similar state-funded assistance programmes provide some access for parties with limited or no financial resources and leaves those not eligible for such assistance without recourse. ${ }^{35}$ In fact, the Canadian Action

28. See 'World Justice Index', available at: <http://worldjusticeproject.org/ sites/default/files/media/wjp_rule_of_law_index_2016.pdf> (last accessed 6 December 2016).

29. See, e.g., Canadian Bar Association, DAS Canada White Paper (May 2014), available at: <www.das.ca/DAS/media/Images/Banners/DAS_ WhitePaper2014_web_vf_1.pdf>, p. 4 ('Adult Canadians accessed the legal system more than 4,250,000 times in the past five years. Less than half had a lawyer to represent them. Why? Mainly due to the costs and time involved with navigating the Canadian legal system.')

30. Ibid. See also Silver and Farrow, above n. 2

31. Ministry of the Attorney General, Ontario, available at: <https://www. attorneygeneral.jus.gov.on.ca/english/about/pubs/cjr/firstreport/cost. php>.

32. CBA Task Force Report, above n. 21, at 12.

33. See, e.g., A.S. Zuckerman, Civil Justice in Crisis: Comparative Perspectives of Civil Procedure (Oxford, Oxford University Press, 1999) at 3-52, where delays are said to be due to an ineffective organisation of civil justice.

34. Ibid., at 16

35. Ibid.
Committee on Access to Justice in Civil and Family Matters recently analysed the (high) costs of justice and noted, in a national report on access to civil and family justice, that

[1] egal fees in Canada vary significantly; however, one recent report provides a rough range of national average hourly rates from approximately $\$ 195$ (for lawyers called in 2012) to $\$ 380$ (for lawyers called in 1992 and earlier). Rates can vary from this range significantly depending on jurisdiction, type of case, seniority and experience.

The cost of civil and family matters also varies significantly. For example, national ranges of legal fees are recently reported to be $\$ 13,561-\$ 37,229$ for a civil action up to trial (2 days), $\$ 23,083-\$ 79,750$ for a civil action up to trial (5 days), $\$ 38,296-\$ 124,574$ for a civil action up to trial (7 days), and $\$ 12,333-\$ 36,750$ for a civil action appeal. The length and cost of legal matters have continued to increase. ${ }^{36}$

Furthermore, judges contribute to the problem of court delays and excessive costs of justice in their handling of cases and their case management. ${ }^{37}$ Judges have a duty to control and sanction time rules and deadlines, and they must steadily respect the principle of proportionality. ${ }^{38}$ In doing so, they must appreciate the issues involved, the timeline of the case, the scope of the opinion or expert evidence and the length of the proposed trial.

Understanding the law is another issue facing Canadians and acting as a barrier to access to justice. Indeed, the 1996 Task Force Report noted that legal information often is unavailable and inaccessible, that the law is too complex for most - particularly its vocabulary, procedures and institutions, and that there remain linguistic, cultural and communication barriers in that regard. ${ }^{39}$ More generally, the 2013 Action Committee highlighted that ' $[\mathrm{t}]$ he civil and family justice system is too complex, too slow and too expensive. It is too often incapable of producing just outcomes that are proportional to the problems brought to it or reflective of the needs of the people it is meant to serve. [...] Major change is needed'. ${ }^{40}$

Equality of justice is noted as yet another barrier to Canadian access to justice, as the justice system is mostly used by corporations and by those individuals with higher means. In a national report arising from an Equal Justice Initiative, the Canadian Bar Association Access to Justice Committee identified four systemic barriers as

36. Action Committee on Access to Justice in Civil and Family Matters, Access to Civil \& Family Justice: A Roadmap for Change (Final Report) (October 2013), available at: <www.cfcj-fcjc.org/sites/default/files/ docs/2013/AC_Report_English_Final.pdf>, p. 4 (Thereinafter 'Roadmap for Change Report').

37. Ibid., at 13 .

38. See, notably, Art. 18 of the Quebec Code of Civil Procedure, which provides that duty of proportionality applies to the parties and the judges.

39. Roadmap for Change Report, above n. 36, at 17

40. Ibid., at 1 . 
blocking Canadian efforts to reach equal justice and proposed ways to overcome them: the lack of public profile and inadequate strategy and coordination, the lack of effective mechanisms for measuring change, the gaps in our knowledge about what works and how to achieve substantive change. ${ }^{41}$

Accordingly, one may conclude that even if the Canadian legal system is considered to be modern and coherent with the guarantees of a fair and equitable justice system, the legal needs of the Canadian public are not truly being met. To better understand how we can better meet those needs, we must look at how civil procedure reforms lead to institutional and societal changes. How do we achieve large-scale reform? Certain authors have advocated the use of a social law approach, which seeks to address and mobilise the stakeholders in a social issue to collaboratively implement prototypes of new processes which are continuously refined in a cycle of evaluation and adaptation', ${ }^{42}$ others have advocated resorting to a 'social lab'43 approach to reform, but I will suggest that what is really needed is an empirical approach involving brainstorming and statistical data from all those actors of the legal system concerned with access to justice. ${ }^{44}$

Throughout the years and various reforms, however, many of the fundamental access to justice issues remain, and some of the core access to justice problems such as court delays and the costs of justice are omnipresent and do not seem to ever completely become resolved. ${ }^{45}$ Hence, lawyers have been encouraged to go beyond the rules and their reform, and to take charge of the change of culture. Indeed, as the 2013 Roadmap for Change Report has highlighted, even if we face serious access to

41. Canadian Bar Association, Equal Justice - Balancing the Scales Report, 2013, at 9, available online at <www.Isuc.on.ca/uploadedFiles/For_the_ Public/About_the_Law_Society/Convocation_Decisions/2014/CBA_ equal_justice.pdf $>$. The report outlines the Committee's proposed strategic framework for reaching equal justice. Based on research and consultations, the framework contains a series of objectives reflecting a consensus on measures for reform in 31 key areas. The objectives are framed as measurable, concrete goals to be achieved at the latest by 2030.

42. J.-P. Boyd, 'A Methodology for Beginning Fundamental Justice Reform', 6 January 2015 (blog entry), available at <http://ablawg.ca/wpcontent/uploads/2015/01/Blog_JPB_Methodology_Justice_Reform_ Jan2015.pdf>.

43. The 'social lab' is defined as a 'multi-stakeholder platform through which a diverse team of stakeholders works together to address a complex challenge'. See <www.slaw.ca/2014/07/14/a-social-lab-for-bcfamily-justice-system/>

44. For an example of such an empirical project involving a search for statistics and raw data, see Class Action Lab Project on Compensation through the Class Action, available at $\langle w w w . c l a s s a c t i o n s l a b . c a /\rangle$; or the Access to Law and Access to Justice Project at the University of Montreal <www.adaj.ca/>.

45. 'For who would bear... the law's delay ...' Hamlet Prince of Denmark, Act III, scene I. In 1539, King Francis I proclaimed the Ordonnance de Villers-Cotterets to 'pourvoir au bien de notre justice, abbréviation des procès, et soulagement de nos sujets' or, in other words, improve the justice system, shorten trials and ease the burden on the King's subjects. Also see M.-J. Longtin, 'Standards for the New Millennium - Meeting Public Expectations - An Assessment of the 2002 Civil Procedure Reform in Québec', Canadian Forum on Civil Justice 2006 Conference: Into the Future, available at: <www.cfcj-fcjc.org/sites/default/files// longtin-en.pdf> (thereinafter 'Into the Future Report'). justice challenges, we must be 'optimistic about our ability to bridge the current implementation gap by pursuing concrete access to justice reforms'. ${ }^{46}$ As the report aptly notes, we must rejoice that the actors of the civil justice system are engaged by access to justice challenges and willing to work hard to reform the law. ${ }^{47}$ Research initiative in Canada such as the University of Montreal's Access to Law and Access to Justice Initiative have sought to link together the actors of the system and to create collaborations between academics and practitioners to force a change in practices and to interpret reforms in a coherent manner. ${ }^{48}$

\section{Reform Processes of Canadian Procedural Law}

Canadian civil justice reform initiatives have been extremely varied, at the level of the legal actors and their discussion papers and formal national reports, and as pertains to politically based initiatives or reforms arising from the government. The procedural reform initiatives have been strongly informed and influenced by the English rules, particularly in light of the Woolf reforms. ${ }^{49}$ They have also been influenced by the US Federal Rules of Civil Procedure. ${ }^{50}$ For example, as they relate to class proceedings. ${ }^{51}$ Of course, the ALI (American Law Institute) and UNIDROIT's (International Institute for the Unification of Private Law) joint project, 'Principles and Rules of Transnational Civil Procedure' (2004) ${ }^{52}$ also represents a source of continual influence in enacting and reforming procedural law rules, particularly as these Principles aim to combine common law and civil law approaches to civil litigation ${ }^{53}$ and to provide standards for adjudication of transnational commercial disputes and most other kinds of civil disputes, in a way as may be the basis for future initiatives in reforming civil procedure.

In recent years, civil justice reform has had a renewed importance and has become a national priority in Cana-

46. Roadmap for Change Report, above n. 36, at 24.

47. Ibid.

48. See ADAJ Project, with its 20 fields of research, each related to one specific aspect of access to justice in Canada, available at: <www.adaj.ca/.

49. See, e.g., The Right Honourable L. Woolf, Access to Justice: Final Report to the Lord Chancellor on the Civil Justice System in England and Wales (Westminster, UK, Her Majesty's Stationery Office, 1996), available at: <http://webarchive.nationalarchives.gov.uk/+/http:/www. dca.gov.uk/civil/final/contents.htm> (Thereinafter 'Woolf Report'); 'Civil Justice Reform Project Consultation Paper' (2006), available at: $<$ www.civiljusticereform.jus.gov.on.ca/files/Consultation\%20Paper \%20(August\%2018,\%202006).pdf>.

50. 113th Congress, 2nd Session, No. 8.

51. See, e.g., C. Piché, Fairness in Class Action Settlements (Toronto, Carswell, 2011).

52. See 'ALI/UNIDROIT Principles of Transnational Civil Procedure', available at: <www.unidroit.org/english/principles/civilprocedure/aliunidroitprinciples-e.pdf $>$.

53. See, e.g., N. Andrews, 'Fundamental Principles of Civil Procedure: Order Out of Chaos', in X.E. Kramer and C.H. van Rhee (eds.), Civil Litigation in a Globalising World (The Hague, The Netherlands, T.M.C. Asser Press, 2012). 
da. As such, when judicial reform is at stake, the general process appears to require that a number of influential groups and entities - such as the different bar associations - support the reform efforts by providing opinions about the state of the law, leading to official or unofficial reports and to rules changes. The procedural reform process tends to be expensive, administrative and highly bureaucratic.

In this subsection, I will first address selected Canadawide, national efforts to reform procedural laws and provide access to justice initiatives and solutions. I will thereafter critically discuss more targeted reform efforts in the provinces of Quebec and Ontario. Finally, I will address more implicit reform efforts affected by way of judicial influences through judicial decisions and public speeches of judges. Throughout the analysis, I will highlight the core objectives of these efforts and the inconsistency of philosophy behind some of the reforms.

\subsection{National Procedural Reform Efforts and Selected Access to Justice Initiatives}

\subsubsection{The 1996 CBA Task Force Report}

In 1995, the System of Civil Justice Task Force was created by the Canadian Bar Association to enquire about the state of the civil justice system on a national basis and to develop strategies and recommendations to facilitate the modernisation of the justice system in order to better meet the needs of Canadians. It sought to render the Canadian civil justice system more 'efficient, accessible, accountable, fair and able to deliver timely results in a cost-efficient manner'. ${ }^{54}$ The Task Force assembled actors from different spheres of the law, including judges, users of the system and governmental and administrative sector actors. ${ }^{55}$ In the report, recommendations were released on a national basis to develop strategies and mechanisms to assist in the modernisation of the justice system, keeping in mind the ultimate objective of preserving and fostering public confidence in the administration of justice. ${ }^{56}$

The Task Force Report concludes that to obtain affordable and timely dispute resolution, a multi-option civil justice system is required, involving a fundamental reorientation away from the traditional adversarial approach and toward dispute resolution. As such, trials are to remain a key component of the civil justice system but are seen as a dispute resolution technique of last resort in a court system that provides many options for resolving disputes. ${ }^{57}$ However, for a multi-option civil justice system to be implemented, courts must focus on early settlement and have a greater control over the progress of cases. ${ }^{58}$ In addition, the Task Force advocates 'increased flexibility and proportionality in procedures through the creation of multiple tracks for dispute resolution'; of 'increased access through improved small

\footnotetext{
54. 1996 CBA Task Force Report, above n. 21, p. III.

55. Ibid.

56. Ibid., at 4-5

57. Ibid., at 6-7.

58. Ibid.
}

claims procedures and the establishment of expedited and simplified proceedings'; of 'specific, and in some cases dramatic, procedural reforms'; of 'changes to the incentive structure in litigation'; and of 'reforms at the appellate level'. ${ }^{59}$

Following the Task Force Report, the Canadian Bar Association and the University of Alberta Faculty of Law established a Canadian Forum on Civil Justice (CFCJ) in May 1998, in response to the report's recommendations. The Forum is a national non-profit organisation that has been dedicated to advancing civil justice reform through research and advocacy since its inception. ${ }^{60}$ Its main goal is to render the civil justice system more accessible, effective and sustainable, through participation in projects that place the citizen at the centre of the civil justice system. ${ }^{61}$ The Forum's Board and Advisory Board include members of the Bar, government, court administration, the judiciary, legal academia and the public, on a national basis.

The Forum's work focuses on the civil justice system of each province, and includes work on access to justice issues, procedural rules, alternative dispute resolution, court administration, technology, public legal education and statistics. It has, in the context of its research projects, conducted hundreds of interviews with Canadian users of the civil justice system seeking to obtain information about expectations relative to our justice system. It has also researched a project entitled 'SelfRepresented Litigants and Unrepresented Accused' and has sought to develop a thesaurus of civil justice system's terminology to improve bilingual and cross-jurisdictional access to the Forum's Clearinghouse and other civil justice information. Finally, it has conducted and is conducting research on the cost of litigation and of justice, which will lead to extensive results in the next year. $^{62}$

59. Ibid., particularly at p. $31 \mathrm{ff}$.

60. See 'Canadian Forum on Civil Justice - About us', available at: <www. cfcj-fcjc.org/about>

61. Ibid. In 2011, the Forum moved from the Faculty of Law at the University of Alberta to York University and is affiliated with Osgoode Hall Law School and the York Centre for Public Policy and Law.

62. The Canadian Forum on Civil Justice is in fact beginning a major international research project entitled: 'The Cost of Justice: Weighing the Costs of Fair and Effective Resolution to Legal Problems'. The project is organized around answering five key questions: What are the costs of pursuing the resolution of legal problems? What are the costs of not achieving resolution? Is the cost of achieving resolution economically and socially warranted? What can be done to effectively prevent disputes, and at what costs and benefits? What choices and changes are recommended based on the available evidence? The underlying hypothesis of the project is that there are huge social and economic costs in delaying or not resolving civil disputes and that in the paradigm for civil justice system funding, these costs are given little weight, in part because they are not well understood. See Canadian Forum on Civil Justice, 'The Cost of Justice: Weighing the Costs of Fair and Effective Resolution to Legal Problems' (2012), available at: <www.cfcj-fcjc. org/sites/default/files/docs/2012/CURA_background_doc.pdf> 


\subsubsection{Forum into the Future Report (2006) ${ }^{63}$}

Ten years after the release of the 1996 Task Force Report, the 2006 Into the Future Report was issued following a two-part Conference entitled 'Into the Future: The Agenda for Civil Justice Reform', held in Montreal and Toronto in $1996 .{ }^{64}$ In conjunction with the Conference, the Forum conducted a research project seeking information about developments since 1996 in the systems of civil justice in Canada, and sought to analyse these developments and structure ideas about the direction reform of the civil justice systems could or should take in the future.

Interestingly, the report listed a series of important recommendations on the themes of the multi-option civil justice system, ${ }^{65}$ reducing delay through court supervision of the progress of cases, ${ }^{66}$ reducing costs and increasing access, ${ }^{67}$ appellate reform, ${ }^{68}$ improving public understanding ${ }^{69}$ managing the courts of the twentyfirst century. ${ }^{70}$ It concluded that the users of the systems suggested the following alterations to the 1996 vision for the civil justice system in 2006 and beyond: increasing the responsibility of litigants and the courts in the application of the proportionality rule and the efficient conduct of proceedings; simplifying procedural rules; making better use of the means of evidence (examinations and opinion evidence); consolidating settlement conferences and management conferences; and making greater use of information technology in the presentation of cases. ${ }^{71}$

\subsubsection{Action Committee on Access to Fustice in Civil and Family Matter's Final Report: Access to Civil E Family fustice: A Roadmap for Change (Final Report) (October 2013)}

Following the release of the 2006 Into the Future Report, Supreme Court of Canada Chief Justice Beverley McLachlin spoke publicly about access to justice issues on a number of occasions. In June 2007, she met with then-Canadian Bar Association President Parker McCarthy to discuss a possible collaboration between the judiciary, the bar and other justice system stakeholders, to find innovative ways to reform the civil justice system. ${ }^{72}$ Following this meeting, representatives of the Canadian Bar Association, the Canadian Fudicial Council and the Canadian Forum on Civil fustice created a national initiative involving several stakeholders to discuss priority issues to improve access to justice in civil and family matters.

63. M.A. Shone, QC, Into the Future: Civil Justice Reform in Canada, 1996 to 2006 and Beyond (Edmonton, Canadian Forum on Civil Justice, 2006), available at: <www.cfcj-fcjc.org/sites/default/files/docs/2006/ shone-final-en.pdf> (Hereinafter 'Into the Future Report').

64. Ibid

65. Ibid., at 9.

66. Ibid., at 18

67. Ibid., at 31

68. Ibid., at 48

69. Ibid., at 57

70. Ibid., at 66

71. Ibid., at $170 \mathrm{ff}$.

72. See <www.cba.org/CBA/Advocacy/pdf/action.pdf $>$, at 1 .
This initiative was the Action Committee on Access to Fustice, which formally became in 2008 the Action Committee on Access to Fustice in Civil and Family Matters. This Committee assembled leaders in the civil and family justice communities and the public, under the leadership of the Honourable Justice Thomas A. Cromwell of the Supreme Court of Canada. It was mandated 'to develop consensus and priorities around improving access to justice and to encourage cooperation and collaboration between all stakeholders in the justice system' ${ }^{73}$ The Action Committee chose to prioritise four topics: court processes simplification, access to legal services, prevention triage and referral and family justice. ${ }^{74} \mathrm{~A}$ few years later, in 2012, the different working groups released 'reports outlining the main access to justice challenges facing each area and providing innovative ideas on how to address and overcome those challenges' ${ }^{75}$

Based on the conclusions of its different working groups, the Action Committee released its Final Report in October 2013. ${ }^{76}$ The report, entitled Access to Civil \& Family Justice: A Roadmap for Change, tackles the difficult problem of access to justice and lays out a series of recommendations to bring a fuller access to justice to Canadians. Part 1 outlines the shared understanding of the notion of access to justice and provides a clear statement and framing of the access to justice problem in Canada. The Committee's view of access to justice, in fact, is much broader than the traditional perspective embraced by the courts, tribunals, judges and lawyers. Access to justice, as such, is conceptualised as a reflection not only of the legal problems subject to legal advice or those problems that are addressed in court, but all of the other legal problems faced by the public with no legal solution.

Part 2 offers six guiding principles designed to help implement a 'culture shift' - a new approach to thinking through civil and family justice reform:

1. Putting the public first by looking at legal problems from the point of view of the people experiencing them, not solely from the point of view of the system.

2. Collaborating and coordinating.

73. Action Committee on Access to Justice in Civil and Family Matters, Colloquium Report, at 1, available at <www.cfcj-fcjc.org/sites/default/ files//docs/2014/ac_colloquium_web_FINAL.pdf >. (Thereinafter 'Colloquium Report').

74. Ibid.

75. Ibid., citing Action Committee on Access to Justice in Civil and Family Matters, Working Group Reports: (1) Report of the Court Processes Simplification Working Group (May 2012), available at: <http://flsc.ca/ wp-content/uploads/2014/10/services2.pdf>; (2) Report of the Access to Legal Services Working Group (May 2012), available at: <http://flsc. ca/wp-content/uploads/2014/10/services3.pdf>; (3) Report of the Prevention, Triage and Referral Working Group, 'Responding Early, Responding Well: Access to Justice through the Early Resolution Services Sector' (May 2012), available at: <www.cfcj-fcjc.org/sites/default/ files/docs/Report\%20of\%20the\%20Prevention\%2C\%20Triage $\% 20$ and $\% 20$ Referral\%20WG\%20.pdf>; (4) Report of the Family Justice Working Group, 'Meaningful Change for Family Justice: Beyond Wise Words' (April 2013), available at: <http://flsc.ca/wp-content/ uploads/2014/10/services5.pdf>

76. Roadmap for Change Report, above n. 36. 
3. Preventing and educating, principally through building the legal capability of the public and encouraging prevention.

4. Simplifying, making coherent, proportional and sustainable reforms. This requires recognising that not every legal problem requires a lawyer.

5. Taking action. The report is a call for action.

6. Focusing on outcomes.

The final guiding principle calls for a shift in focus from process to outcomes:

We must be sure our process is just. But we must not just focus on process. We should not be preoccupied with fair processes for their own sake, but with achieving fair and just results for those who use the system. [emphasis added] $]^{77}$

Finally, Part 3 of the report offers a nine-point access to justice 'roadmap' meant to bridge the gap between ideas and action, which contains the essence of its proposals for innovative civil justice reform: ${ }^{78}$

A. Innovation Goals

1. Refocus the Justice System to Reflect and Address Everyday Legal Problems

2. Make Essential Legal Services Available to Everyone

3. Make Courts and Tribunals Fully Accessible Multi-Service Centres for Public Dispute Resolution

4. Make Coordinated and Appropriate Multidisciplinary Family Services Easily Accessible

B. Institutional and Structural Goals

5. Create Local and National Access to Justice Implementation Mechanisms

6. Promote a Sustainable, Accessible and Integrated Justice Agenda through Legal Education

7. Enhance the Innovation Capacity of the Civil and Family Justice System

C. Research and Funding Goals

8. Support Access to Justice Research to Promote Evidence-Based Policy Making

9. Promote Coherent, Integrated and Sustained Funding Strategies. ${ }^{79}$

This nine-point access to justice roadmap is intended to be an innovative guide for local initiatives. It highlights the need for a coherent and sustained funding strategy, including enhanced funding for legal aid. Moreover, it calls for support for research to better promote evidence-based policy choices. Importantly, it supports the fundamental proposition that citizens must have confidence in the civil justice system and have the knowledge and attitudes required to proactively prevent and resolve their legal disputes, all in the interest of justice and the rule of law. ${ }^{80}$

\subsection{Critical View of Two Provincial Efforts to Reform Procedural Laws and Civil Justice Systems}

\subsubsection{Quebec's Nem Fudicial Culture}

In the province of Quebec, a Code of Civil Procedure of Lower Canada ${ }^{81}$ was first enacted in 1866 , following the Civil Code of Lomer Canada, ${ }^{82}$ and based on the contemporary French codes of civil procedure. ${ }^{83}$ This first real code sought to 'consolidate, compile and reconcile all the diverse existing sources of procedural law'. ${ }^{84}$ The 1897 second official Code of Civil Procedure brought Quebec civil procedure much closer to the English adversarial system with concepts of examination in chief and cross-examination being introduced. ${ }^{85} \mathrm{~A}$ 'complete revision of the old [1897] Code', ${ }^{86}$ came about with the third 1965 code, a Code of Civil Procedure, ${ }^{87}$ which fundamentally expressed procedural law as an auxiliary to substantive law in its Article 2. That Code was partially amended over the years since. ${ }^{88}$ The 2014 Code of Civil Procedure is the fourth procedural law recodification project in the province's history, after several instances of substantial revision to existing codes. This newest Code of Civil Procedure came into force on 1 January 2016.

Importantly, it must be highlighted that the two most recent procedural law reforms in Quebec have resulted from consultations with different justice actors, judicial law specialists and judges, and with the general population. In 1998, a fundamental revision of the rules was envisaged in view of facilitating access to civil justice. A committee of experts named the 'Civil Procedure Review Committee' was created, and was led by Laval University Professor Denis Ferland. The Committee's mandate was to review the rules of civil procedure to limit their number, to simplify the procedures and to take into consideration the alternative modes of dispute resolution. ${ }^{89}$ The Committee identified several important access to justice problems, such as the cost of procedures, the length of time to trial, the complexity of the law and certain administrative issues. ${ }^{90}$ During the con-

81. Act respecting the Code of Civil Procedure of Lower Canada, S Prov C 1866 (29-30 Vict), c 25 [1866 Code].

82. See J.E.C. Brierley, 'The Renewal of Quebec's Distinct Legal Culture: The New Civil Code of Quebec', 42 UTLJ 484 (1992).

83. See Lac d'amiante, where the Court cited the introduction of M. Tancelin, 'How can a legal system be a mixed system?', in F.P. Walton (ed.), The Scope and Interpretation of the Civil Code of Lower Canada (1980), 1, at 1, 9 and 10; also R. Jukier, 'The Impact of Legal Traditions on Quebec Procedural Law: Lessons from Quebec's New Code of Civil Procedure', 93 Can. Bar Rev. 1 (2015); J.-M. Brisson, La formation d'un droit mixte: l'évolution de la procédure civile de 1774 à 1867 (1986), at 32-33.

84. Jukier, above n. 83, at 13.

85. Code of Civil Procedure, SQ 1897, c 48 [1897 Code].

86. Jukier, above n. 83, at 16.

87. Code of Civil Procedure, RSQ, c C-25 [1965 Code] (formerly SQ 1965, c 80), which came into force on 1 September 1966.

88. See, e.g., Lac d'amiante; Jukier, above n. 83.

89. See, e.g., Civil Procedure Review Committee, 'A New Judicial Culture', available at: <www.justice.gouv.qc.ca/english/publications/rapports/ pdf/sommaire-a.pdf>

90. Ibid 
sultation project, the Committee sought the views of many legal practitioners in different areas of practice and held a number of public consultations. It issued several recommendations for future reform, providing a new direction and a renewed impetus to procedural law reform with a series of cornerstone principles - for instance, the cornerstone principle of proportionality, case management by the judge and the mastering of the case by the parties. ${ }^{91}$

The Committee's final report was issued in 2001 and was noticeably entitled 'A New Judicial Culture', 92 thereby revealing the fundamental essence of its recommendations. The Committee's report was divided into three main parts. The first part addressed six findings fundamental to the Committee in understanding the state of the justice system and of its necessary focus. The second part proposed a new vision of civil procedure and of the civil justice system. The third part analysed the current rules of civil procedure, identified the principal access to justice issues and listed recommendations for reform that would provide the foundation for a new Code. These recommendations related to seven themes: the values of justice, the guidelines and the general rules; the jurisdiction and the organisation of the courts; the introduction and conduct of the proceedings; the production of evidence; the judgment, costs and the means to contest a judgment; the particular matters such as non-contentious matters, family matters, boundaries of land, arbitration, recovery of small claims, class action, provisional measures, private international law; and the execution of judgments. ${ }^{93}$

Following the report, a draft bill was tabled to reform the rules of civil procedure. Through this bill, the Ministry of Justice sought to bring changes to adversarial procedure in first instance proceedings by shortening the time limits within which a case must be ready for scheduling with the introduction of a peremptory time limit of 180 days from the date of service of the motion, reinforcing litigant accountability and increasing the role of judges in case management and establishing new cornerstone principles that would govern civil procedure. ${ }^{94}$ The bill further gave judges a much more active role in the pre-trial process by treating them as 'case managers' that would help ensure the orderly progress of the proceedings and the proper management of the case. Small claims procedure was also completely revised. A new process of judicial settlement conferences was established. The legal community was consulted, and a meeting was held in 2002 by and between judges, the Quebec Bar and the Quebec Ministry of Justice to discuss the draft bill. The bill was passed on 6 June 2002, and came into force on 1 January 2003. ${ }^{95}$

91. Ibid

92. Ibid.

93. Ibid., at 4.

94. Act to reform the Code of Civil Procedure, Bill No. 54, Chapter 7, enacted on 6 June 2002 and assented to on June 8, 2002; Longtin, above n. 45 , at 2

95. Act to reform the Code of Civil Procedure, Bill No. 54, Chapter 7, enacted on 6 June 2002 and assented to on 8 June 2002.
In the end, the 2003 amendments implemented the Nem Fudicial Culture Report's essence and recommendations, introducing significant reforms to the Québec Code of Civil Procedure, all revolving around three goals: the simplification of proceedings, the reduction of delays and the control of costs. ${ }^{96}$ The cornerstone principle of the reform, however, was the Lord Woolf-inspired principle of proportionality, which requires judges, lawyers and clerks to consider that proceedings (and since then, by interpretation, the presentation of evidence) are to be cost and time effective in relation to the nature and purpose of the action or application and the complexity of the issues. ${ }^{97}$

In March of 2006, another official report was published evaluating the impact and consequences of the 2003 reform, as required by Section 180 of the Act to reform the Code of Civil Procedure. ${ }^{98}$ Pursuant to that section, the minister reported to the government on the implementation of certain components of the reform, including the 180-day peremptory time limit for case readiness, oral defences and the other major changes to the Code of Civil Procedure. The report evaluated the major changes introduced by the legislation and made recommendations for future reform directions. Among the important issues examined in the report were: the principle of proportionality, the time limit within which a case must be ready for scheduling, case management, applications to the court, dispute settlement, the appeal process for small claims, class actions, the use of technology and witness fees. ${ }^{99}$ It was later tabled in the National Assembly.

Quebec's most recently reformed Code of Civil Procedure resulted from discussions about a more formal draft bill, tabled in 2011 at the National Assembly by the Minister of Justice, ${ }^{100}$ and 49 briefs submitted during the public consultation process that was held in 2012. In April 2013, the Minister of Justice tabled the new bill, which was subjected to public consultations where 14 groups were heard and 21 briefs were submitted. The bill was examined before a lengthy parliamentary committee and 30 sittings. A total of 330 amendments and 5 subamendments were adopted.

On 20 February 2014, Bill 28, An Act to establish the nem Code of Civil Procedure, was passed by the National Assembly, ${ }^{101}$ with procedural rules guaranteed to have a significant impact and lasting effects on access to

96. Ibid

97. See, e.g., C. Piché, 'Figures, Spaces and Procedural Proportionality', International Journal of Procedural Law (2012) JPL-RIDP.

98. Ministère de la Justice, Le Rapport d'évaluation de la Loi portant réforme du Code de procédure civile, LQ 2002, c 7 (Québec: Ministère de la Justice du Québec, 2006), available at: <www.justice.gouv.qc.ca/ francais/publications/rapports/pdf/crpc/crcprap-4.pdf>. That Section provides that the Minister of Justice must carry out an assessment of the implementation of the reform three years after its coming into force.

99. Longtin, above n. 45, at $4 \mathrm{ff}$

100. Bill 28, An Act to Establish the New Code of Civil Procedure, 2nd Session, 39th Leg, Quebec, 2014 (later assented to on 20 February 2014)

101. Ibid 
justice. ${ }^{102}$ The newest Code of Civil Procedure came into force on 1 January 2016. Importantly, this Code has sought to mitigate the perennial problems of contemporary justice systems, that is, complexity, cost and delays. Designed to ensure 'the accessibility of justice, the promptness of justice, the proportionate and economical application of procedural rules and the inculcation of a spirit of cooperation in the exercise of parties' rights', 103 the Code's breadth and scope has been considered as a game-changer for Quebec citizens' access to justice.

On the one hand, what the Quebec legislator has done with this new Code is prioritising private modes of dispute resolution by making the 'consideration' of such modes mandatory before addressing the courts ${ }^{104}$ and generally presenting private modes as the 'better' solution in their legislative presence and order as within the Code, ${ }^{105}$ thereby consecrating the importance of informal procedures and the control (mostly of the choice of proceedings) by the parties. On the other hand, the legislator has given 'superpowers' ${ }^{106}$ to judges to intervene at various stages of the proceedings, formalising their management of the case and thereby diminishing the involvement of the parties as well as their mastering and control of the case. ${ }^{107}$ Moreover, the need for efficiency was emphasised in the Code's Preliminary Provision, thereby suggesting that the appreciation of justice needs and outcomes must be made according to accounting standards.

While reform is in theory justifiable by the need to control costs and delay, it appears to be founded upon a need to evacuate from the system those cases that are not 'worthwhile' and do not need to be addressed judicially. The question is, however, which such cases should be staying within the system, and how does one determine whether they are justiciable? Furthermore, this evacuation of certain cases from the list of justiciable cases involves a tighter control of cases through case management and consideration of efficiency objectives. This renewed control and the judges' superpowers leads to case files being appreciated in terms of profit and success at a rapid, low-cost, pace. A new system is thus created where court users become 'clients' of sorts of the civil justice system instead of being treated as mere beneficiaries of the law. This focus in our civil justice system on efficiency is problematic if one considers how fundamental just and equitable processes are to society. Efficiency must be considered simultaneously with fairness and justice.

Interestingly, in Quebec, civil procedure reforms have taken into consideration the opinion of the public. As such, reform proposals have been discussed in parlia-

102. See <www.justice.gouv.qc.ca/english/sujets/glossaire/code-proc-a. htm>.

103. Jukier, above n. 83 , at 19 .

104. Art. 1, al. 3, Quebec Code of Civil Procedure.

105. See Arts. 1-7 and 417ff., Code of Civil Procedure.

106. See C. Piché, 'Un juge extraordinaire', Le Code de procédure civile: quelles nouveautés ? (Université Laval, Québec, Éditions Cahiers de droit, 2017) at 223-244.

107. Ibid mentary committees and have frequently the subject of public consultation. In 2000, and again in 2012-2013, civil procedure reform proposals were opened up for public comment and consultation. While these reform efforts have often been extraordinary and meaningful in providing a true wind of change, justice remains lengthy and expensive, and subject to a 'perfect storm', which aggravates the situation of access to justice in Canada not only in civil but also in criminal cases. ${ }^{108}$ Indeed, cases still take more than five years on average to come to a resolution, and the cost to the taxpayer of each day of trial has been estimated at CAN\$10,000.109

\subsubsection{Ontario Civil Fustice Reforms}

In Ontario, ongoing efforts have similarly been made to reform the rules of civil procedure that were originally dominated by the old British common law forms of action - and eventually abandoned in $1881 .^{110}$ In 1837 , the judges of the Court of King's Bench in Upper Cana$\mathrm{da}^{111}$ began working on practice and pleading rules and eventually finalised these rules by $1841 .{ }^{112}$ The rules were found to be unsatisfactory and led to the Common Lam Procedure Act, $1856,{ }^{113}$ which established the practice that would govern until 1881, when common law and equity courts merged into one single superior court. $^{114}$

A few years later, the Ontario Fudicature Act, 1881 introduced new rules of practice to replace the rules applicable to the common law courts and the Court of Chancery. The former practice in the Court of Chancery was then abolished. ${ }^{115}$ Over the following years, judges introduced new consolidated sets of rules of practice, ${ }^{116}$ and continued to do so until the Fudicature Amendment Act, 1941, ${ }^{117}$ which amended the Fudicature Act to establish a Rules Committee. ${ }^{118}$ Practising lawyers were then appointed to the rules enactment Committee. In 1984, the Courts of Fustice Act ${ }^{119}$ renamed the Rules Committee as the Civil Rules Committee. ${ }^{120}$

In 1985, the contemporary Ontario Rules of Civil Procedure were finally enacted, ${ }^{121}$ offering a complete revision and reorganisation of the existing Rules of Practice. Many changes were later made to the rules, between 1985 and 2010, notably with regard to simplified proce-

108. See the expression as is being used in the media to describe the Quebec justice system, available at: <www.tvanouvelles.ca/2016/12/01/lesysteme-de-justice-frappe-par-une-tempete-parfaite-dit-lisee-1>.

109. P.-C. Lafond, L'Accès à la Justice Civile au Québec (Montréal, Éditions Yvon Blais, 2012) at 59

110. J.W. Morden and P.M. Perell, The Law of Civil Procedure in Ontario (1st edn., Toronto: LexisNexis, 2010) at 26-27

111. The Province of Upper Canada (French: province du Haut-Canada) was a part of British Canada established in 1791 by the United Kingdom.

112. Ibid

113. Common Law Procedure Act, S.U.C. 1856 (19 Vict.), c. 43.

114. Morden and Perell, above n. 110, at 28.

115. Ibid

116. Ibid.

117. S.O. 1941 , c. 24 . Also see Morden and Perell, above n. 110, at 29-30

118. Ibid.

119. S.O. 1984 , c. 11 . Also see Morden and Perell, above n. 110, at 29-30.

120. Ibid.

121. Now R.R.O., 1990, Reg. 194. Also see Morden and Perell, above n. 110 , at $29-30$. 
dure, deemed undertakings, mandatory mediation and class proceedings. ${ }^{122}$

Important changes came about following a Civil Justice Reform Project and its recommendations made by the Honourable C.A. Osborne: the proportionality rule, the use of a timetable to schedule proceedings, the definition of the duties of an expert, amendments to the summary judgment rule, discovery plans, the empowerment of judges and masters in hearing certain motions, and finally, a new civil case management rule. ${ }^{123}$

In 1996, the Ontario Civil Justice Review Committee issued a final report providing an overall strategy to streamline Ontario's civil justice system. The Canadian Bar Association, in parallel, released recommendations on a national basis to develop strategies and mechanisms to assist in the modernisation of the justice system. ${ }^{124}$

In 2001, the Government of Ontario and the Superior Court of Justice appointed the Task Force on the Discovery Process in Ontario to identify problems with discovery and to make reform recommendations. In a 2003, the Task Force found that discovery can result in unacceptable cost and delay in large complex cases, or where there is a lack of cooperation between opposing counsel, which can thereby impede access to justice. 4 The Task Force made recommendations on two fronts. The first was the incorporation of enhanced cost- and time-saving mechanisms into the Rules of Civil Procedure. However, the Task Force acknowledged that not all discovery problems could be addressed simply by the imposition of more rules, and noted that many could be attributed to the adversarial 'culture of litigation', or the conduct of particular lawyers. Accordingly, the Task Force made a second set of recommendations for the development of best practices to be adopted by the bench and the bar as appropriate conventions or norms for the conduct of discovery.

In Ontario, the Civil Fustice Reform Project was initiated in 2006, and led by the Honourable Coulter Osborne (a former Associate Chief Justice of Ontario), with a view to proposing options to reform the civil justice system to make it more accessible and affordable to Ontarians. The Law Society of Ontario then participated in the consultations that informed the report. A formal Osborne-authored summary report was published on 22 November 2007. ${ }^{125}$ The full report was released in 2008. The Osborne report first provided a historical review in which it highlighted the several decades of major court reform in Ontario. ${ }^{126}$ It recognised that, despite the many contemporary issues related to access to justice, the reforms were generally successful. ${ }^{127}$

122. Morden and Perell, above n. 110, at 31-32

123. Ibid., at 32-33.

124. See CBA Task Force Report, above n. 21.

125. Hon. C.A. Osborne, Q.C., Civil Justice Reform Project - Summary of Findings and Recommendations (November 2007), available at: <www. attorneygeneral.jus.gov.on.ca/english/about/pubs/cjrp/CJRP-Report_ EN.pdf> (Thereinafter 'Osborne Report').

126. Ibid.

127. Ibid.
In parallel to the Civil Justice Reform project, in March 2006, the Advocates' Society held a Policy Forum, entitled Streamlining Fustice, to search for creative ways to promote efficient, less expensive dispute resolution in our courts, such that access to justice may be enhanced. 5 And in May of 2006, the Canadian Forum on Civil Justice hosted a national conference entitled 'Into the Future: The Agenda for Civil Justice Reform', which has been previously discussed.

Following the Civil Fustice Reform Project: Summary of Findings and Recommendations (2007) (the Osborne Report), Ontario amended the Rules of Civil Procedure to increase access to justice in $2010^{128}$ and again significantly in 2015. The 2010 Rules brought significant changes. The scope of discovery was restricted and the time available for discovery was limited in such a way as to save litigants time and money, ${ }^{129}$ proportionality was considered on all motions relating to discovery, ${ }^{130}$ parties were required to agree on a discovery plan and to do so according to SEDONA Electronic Discovery Principles, ${ }^{131}$ pre-trial conferences became mandatory ${ }^{132}$ and the expert's role, responsibility and duty to assist court were defined. ${ }^{133}$

Ten years later, many of the Civil Justice Review and 1996 Task Force reports' recommendations have been implemented in Ontario, and elsewhere throughout Canada. As for Ontario's civil justice reform strategy, it has been recognised as significantly enhancing access to justice. But cost and delay issues remain, as in many other judicial systems around the world.

\subsection{Judicial Influences in Procedural Law and} Access to Justice Reform

In this article, I have explained that procedural law reforms principally arise from legislative action, frequently following reports and recommendations from provincial or national legal working groups, consultative teams and/or task forces. Apart from the messages sent to legislators through these entities, I will argue that judges too have sought - even if implicitly - to influence procedural law and access to justice reforms in their judicial decisions of course, but also in speeches delivered to the public, or to law professionals or students. They have attempted to go beyond their traditional role of applying the law, ${ }^{134}$ to send messages and interpret the law to trigger a change in culture.

One first example of the judge's role in law reform in Canada is the 2014 Supreme Court of Canada's holding in Hryniak v. Mauldin. ${ }^{135}$ The Supreme Court then

128. Ontario Rules of Civil Procedure, R.R.O. 1990, Reg. 194

129. See rules 30,31 and 76 of the Rules, ibid.

130. Rule 29.2.03 of the Ontario Rules.

131. Rule 29.1 of the Ontario Rules.

132. Rule $50.01 \mathrm{ff}$. of the Ontario Rules.

133. Art. 4.1.01 of the Ontario Rules of Civil Procedure. The expert must be fair, objective and non-partisan. He is to provide opinion evidence that is related only to matters that are within his area of expertise.

134. S. Smith, 'Why Must Courts Obey the Law?', 77 Georgetown Law Journal 113 (1988-1989) at 113-64. Also see H.L.A. Hart, The Concept of Law (2nd edn., Oxford: Oxford University Press, 1994).

135. Hryniak v. Mauldin, 2014 SCC 7, [2014] 1 S.C.R. 87 
called for a 'culture shift' in the approach to summary judgment and the civil justice system more generally. Emphasising the ambitious goal of reducing protracted, costly litigation that undermines access to justice, while ensuring the fair and just adjudication of disputes, the Court released a much anticipated decision addressing summary judgment motions and lowering the bar for obtaining such judgments. The Supreme Court recognised that trials are not required to decide all cases and that other, less costly forms of adjudication are equally legitimate. It cautioned that the rule of law can become threatened when ordinary citizens cannot access all forms of justice, sending a genuine message that access to justice is the 'greatest challenge' to the rule of law, ${ }^{136}$ and signalling its difference in approach to the changes made to the Ontario Rules of Civil Procedure:

[...] Trials have become increasingly expensive and protracted. Most Canadians cannot afford to sue when they are wronged or defend themselves when they are sued, and cannot afford to go to trial. Without an effective and accessible means of enforcing rights, the rule of law is threatened. Without public adjudication of civil cases, the development of the common law is stunted. ${ }^{137}$

For the Supreme Court, a 'culture shift' is required to promote 'timely and affordable access to the civil justice system', 138 and will come from 'simplifying pre-trial procedures and moving the emphasis away from the conventional trial in favour of proportional procedures tailored to the needs of the particular case'. ${ }^{139}$ As such, the Court essentially set out to 'dethrone the conventional trial as the gold standard for adjudication'.140 Admitting that 'trial is not a realistic alternative for most litigants', 141 the Court embraced the need for 'new models of adjudication [that] can be fair and just', ${ }^{142}$ and triggered a culture shift founded upon the principle of proportionality ${ }^{143}$ by accepting that motions for summary judgment can replace traditional adjudication at trial. Interestingly, the Hryniak case largely has been applied in Ontario and elsewhere in Canada, such as to expand the use of the summary judgment process in Ontario to cases of 'all sizes and shapes'. ${ }^{144}$ It has also been used and referred to more generally, in other, non-summary

136. Ibid., para. 1

137. Ibid., para. 1.

138. Ibid., para. 2

139. Ibid.

140. S. Chaudhury, 'Hryniak v. Mauldin: The Supreme Court Issues a Clarion Call for Civil Justice Reform', Adv $J 7$ (2014) at 9.

141. Ibid., para. 4

142. Hryniak v. Mauldin, para. 2.

143. Ibid., para. 29.

144. See, for instance, Density Group Limited v. HK Hotels LLC, 2014 ONCA 605; Sweda Farms Ltd v. Egg Farmers of Ontario, 2014 ONSC 1200, 2014 ONCA 878 ('Summary judgment motions come in all sizes and shapes, and this is recognized in the Supreme Court of Canada emphasis on "proportionality" as a controlling principle for summary judgment motions. This principle does not mean that large, complicated cases must go to trial, while small, single-issue cases should not...'), leave to appeal to SCC refused. judgment cases, to oppose and object to trials by ambush, ${ }^{145}$ or to refuse to convert an application into an action. ${ }^{146}$ Hence, Hryniak is one great example of how Canadian courts can help interpret reformed rules of civil procedure and trigger shifts in our legal culture.

In other contexts, judges speak at public occasions and events and often provide a clear, distinctive, insight as to their visions of access to justice. On three recent occasions, Chief Justice of Canada, Beverley McLachlin, spoke publicly to emphasise, respectively, the place of citizens in the access to justice equation, the concerted action of the legal profession and of legal academics to make court processes more efficient and flexible, and the role of lawyers and the legal profession to solve the access to justice crisis.

On a first and most recent occasion, in inspiring remarks delivered to the Council of the Canadian Bar Association at the Canadian Legal Conference on 11 August 2016, Chief Justice Beverley McLachlin reminded us that citizens must have confidence and use the system to make it 'accessible':

I believe meeting the challenge of providing access to justice to ordinary Canadians must be a top priority, if we are to maintain public confidence in the justice system. If people are excluded from the system, if they conclude it exists only to serve the interests of the elites, they will turn away. Respect for the rule of law will diminish, and our society will be the poorer. ${ }^{147}$

More recently, on 3 June 2016, the Honourable Justice McLachlin again argued very persuasively that a concerted, ingenuous approach to the problem is necessary:

Court proceedings are too expensive, and often take too long. We may have Cadillac justice for the elite and large corporations, but too often ordinary Canadians find themselves shut out of court or forced to go it alone without a lawyer. Courtrooms are filled with unrepresented litigants trying to navigate the system as best they can, increasing strains on the process and triggering yet further delays. Legal aid in many parts of the country is woefully inadequate.

Some, surveying the magnitude of the problems, use the word "crisis". I remain cautiously optimistic. Canadians are taking up the challenge of making access to justice a reality. The National Action Committee has brought governments, lawyers, judges and members of the public together to study strategies for access in family and civil matters. Other groups are engaged in improving access in other areas of the law. Across the country, Attorneys Generals, the legal profession and legal academics are putting their collective shoulder to the wheel to make court processes more efficient and flexible. We have learned that "one size fits all" systems don't mork, and

145. See, e.g., Bosworth v. Colemen, 2014 ONSC 6135

146. See, e.g., Blackberry Ltd v. Marnineau-Mes, 2014 ONSC 1790.

147. See copy of Remarks, available at: $<w w w . s c c-c s c . c a / c o u r t-c o u r / j u d g e s-$ juges/spe-dis/bm-2016-08-11-eng.aspx>. 
that ingenuity, aided by technology, goes a long way. Above all, we have learned that although the problem is polycentric and complex, we can, with effort and intelligence, make a dent in it.

[...] If people are excluded from the system, if they conclude it exists only to serve the interests of the elites, they will turn away. Respect for the rule of law will diminish. Our society will be the poorer. [our italics $]^{148}$

Finally, on 14 August 2015, Chief Justice McLachlin argued that lawyers are central to the access to justice problem and must act as 'servants of justice' and provide services to the people they are meant to serve:

The cry for access to justice is rising from what was once a dull murmur to a crescendo. Other actors including courts and governments - bear much of the responsibility. But lawyers can be a big part of the solution. Everyone needs justice. Lawyers hold the key to the exclusive domain called justice. But they open the doors only to a privileged few, the critics charge.

The sad truth is that around the morld, the legal profession and the courts are often not fulfilling the expectations of consumers of legal services. Legal systems everywhere are experiencing an access to justice crisis that cries out for innovative solutions. Legal aid funding and coverage is not available for most people and problems, and the cost of legal services and length of proceedings is steadily increasing.

[...] As servants of justice, lamyers have a duty to help solve the access to justice crisis that plagues our legal systems. It is vital to the rule of law. And finally, it is vital to the future of the profession. If the legal profession fails to meet the demands of the public for prompt and affordable justice, people in search of justice will go elsewhere, rendering the legal profession increasingly irrelevant. [our italics] ${ }^{149}$

Accordingly, my argument here is that on these three occasions, as well as on many others, ${ }^{150}$ the court has served - even if indirectly - to trigger change. In these instances, the Court has suggested ways in which to answer - and solve, truly - the access to justice crisis.

148. See, e.g., 'Canada's Legal System at 150: Democracy and the Judiciary', Remarks of the Right Honourable B. McLachlin, P.C., available at: $<$ www.scc-csc.ca/court-cour/judges-juges/spe-dis/bm-2016-06-03eng.aspx>.

149. See 'The Legal Profession in the 21st Century', Speech, available at: $<$ www.scc-csc.ca/court-cour/judges-juges/spe-dis/bm-2015-08-14eng.aspx>.

150. See, e.g., Supreme Court of Canada speeches, available at: $<w w w . s c c-$ csc.ca/court-cour/judges-juges/spe-dis/index-eng.aspx>.

\section{Conclusion: Proposed Directions for Access to Justice Reform}

I have acknowledged in this article the tension between the objectives of judicial efficiency, on the one hand, and prioritised private modes of dispute resolution and informal justice in Canadian access to justice initiatives. In light of the reform initiatives herein outlined, it is fair to conclude that Canada has shown a resolute commitment to significant procedural legal change. Access to justice and procedural reforms are the result of a dynamic process involving a variety of legal actors, public consultations, research and information, as well as coordinated efforts on the national and provincial levels. Fundamental new thinking has been generated relative to access to justice as a result of the major 1996 Task Force Report, the 1997 Osborne Report, the 2006 Into the Future Report, and finally, the 2013 Roadmap for Change Report. Discussions are active and ongoing between all legal actors; a true desire for a greater access to justice for Canadians is present, as per legislative reforms, political debates and speeches and public policy headlines.

The approach to procedural law reform has coincidentally evolved as well. The Access to Legal Services Working Group of the 2008 Action Committee on Access to Justice in Civil and Family Matters has concluded that solutions to the access to justice crisis in Canada require that the issue be viewed from the perspective of ordinary Canadians, those people who actually experience legal problems. It has further held that Canadian legal services must be reformed, and that they must be provided through a wider range of service providers than those traditionally available, such as paralegals and pro bono counsellors.

An increasing number of legal actors are working hard together toward change, to enhance access to justice in Canada. However, the foremost key to change in our civil justice system, in my view at least, lies in the greater use of technologies in the courts and in the provision of justice. ${ }^{151} \mathrm{I}$ believe that technology will serve to challenge and transform the legal industry such as to provide new forms of legal service delivery and enhanced communications, as well as more efficacious legal management systems, the whole in line with providing an enhanced access to justice to all Canadians. While we are increasingly seeing e-filings, e-registries and centralised case management information systems, as well as digital recording equipment and video-conferencing in courtrooms throughout Canada, more must be done. The attitudes of judges and lawyers must evolve. We must persuade these actors to trust technologies enough to see them as the vehicle for change in their civil cases.

151. C. Piché, 'Dimensions contemporaines de la preuve civile québécoise à la croisée des catégories du droit', Dalloz - Thèmes et commentaires (2015) at 15. 
With technology will come efficiency and fairer resolutions of disputes both out of courts and in courts. 